P.V. Stavnichenko,

L.O. Novohatska,

A.M. Antonenko, O.P. Vavrinevych

\section{ASSESSMENT OF ECOTOXICOLOGICAL HAZARD AND RISK OF GROUNDWATER CONTAMINATION WITH DIFFERENT GROUPS OF PESTICIDES}

Institute of Hygiene and ecology (HEI) of O.O. Bogomolets National medical university

Hygiene and ecology department

Peremogy av., 34, Kyiv, 03057, Ukraine

Інститут гігієни та екологї̈ Національного медичного Університету ім. О.О. Богомольия

кафедра гігієни та екологї

пр. Перемоги, 34, Київ, 03057, Украӥна

e-mail: elena-vavrinevich@ukr.net

Key words: pesticides, ecotoxicological risk, groundwater, herbicides, insecticides, fungicides

Ключові слова: пестициди, екотоксикологічний ризик, підземні води. гербіцииди, інсектиџиди, фунгіцииди

\begin{abstract}
Assessment of ecotoxicological hazard and risk of contamination of groundwater with different groups of pesticides. Stavnichenko P.V., Novohatska L.O., Antonenko A.M., Vavrinevych O.P. The aim of our work was to determine ecotoxicological risk of herbicides, insecticides, fungicides of different chemical classes with different mechanisms of action by the method of Melnikov M.M. and leaching potential index by the method of Sergeev S.G. and co-workers. It was established that in soil and climatic conditions of Ukraine ecotoxicological hazard of studied herbicides by (1-6) orders of magnitude, fungicides - by (3-5) orders, insecticides - by (2-3) orders lower than DDT. The least ecotoxic are herbicides of the last generations, then fungicides and the most ecotoxic are insecticides and herbicides of the old first generations. It was proved the high danger of groundwater contamination with studied herbicides, insecticides and fungicides, except for mesotrione, the application of which has moderate danger in the soil and climatic conditions of Ukraine. It was shown that in soil and climatic conditions of Ukraine, ability of migration from the soil into groundwater of metribuzin, thiamethoxam, paclobutrazole is high, topramezone and mesotrionemoderate, for other substances - low; in terms of hygienic standards in the ground itallows to avoid them getting into the soil flow and minimize the danger of groundwater contamination to public health
\end{abstract}

Реферат. Оцінка екотоксикологічної небезпечності та ризику забруднення підземних вод різними групами пестицидів. Ставніченко П.В., Новохацька Л.О., Антоненко А.М., Вавріневич О.П. Метою роботи була оцінка екотоксикологічної небезпечності гербіџидів, інсектищидів, фунгіџидів різних хімічних класів з різним механізмом дії за методом Мельникова М.М. та індексу вимивання в трунтові води за методом Сергєєва С.Г. та співавторів. Встановлено, щзо в трунтово-кліматичних умовах України екотоксикологічний ризик досліджуваних гербіцидів на (1-6) порядків, фунгіцчидів - на (3-5) порядків, інсектицидів - на (2-3) порядків нижче, ніж ДДТ. Найменш екотоксичними є гербіцииди останніх поколінь, за ними йдуть фунгіциди, а найбільш екотоксичні - інсектициди та гербіцици старих генерацій. Доведено високу небезпечність забруднення підземних вод у трунтово-кліматичних умовах Украӥни досліджуваними гербіцицами, інсектицидами та фунгіцидами, за винятком мезотріону, при застосуванні якого існує середня небезпечність. Показано, щуо в трунтово-кліматичних умовах Украӥни здатність міграції з трунту в підземні води метрибузину, тіаметоксаму, паклобутразолу - висока, топрамезону та мезотріону - середня, для решти речовин - низька, щзо за умови дотримання гігієнічного нормативу в грунті дозволяє уникнути їх потрапляння 8 трунтовий потік та мінімізувати небезпечність забруднення підземних вод для здоров'я населення.

Introduction. Population growth, industrial development and intensification of agriculture in Ukraine led to increased pollution of the environment with ecotoxicants. Many toxic substances entering the atmosphere, soil and water sources cause a negative impact on autochthonous flora of surface water and soil, plants, animals and human [17].
Among these ecotoxic substances pesticides occupy a special place. First of all, because they are designed to killing and limitation of living organisms - weeds, pathogens of plants, insects and rodents. However, pesticides are potentially harmful both for many species of flora and fauna and for humans. 
Therefore, assessment of environmental safety of pesticides and risk of their application is mandatory for their development and registration $[10,15]$.

Therefore, the aim of our study was to assess the ecotoxicological risk of herbicides, insecticides, fungicides of different chemical classes with different mechanisms of action.

\section{MATERIALS AND METHODS}

For the calculation of ecotoxicological risk, so-called ecotox, the method proposed by M.M. Melnikov was used for assessment of potential risk of fungicides, insecticides, herbicides application for ecosystems and biocenosis [11].

Mathematical modeling method that provides calculatied reproduction of process of pesticides destruction by actual data to predict their persistence was used for calculaion of half-life periods $\left(\mathrm{DT}_{50}\right)$ of substances in the soil $[13,14]$.

For the prediction of groundwater pollution with studied pesticides, calculation of integrated vectors of hazard according to Sergeev S.G. et al. methodology was used [6]. The calculated indicator values expressed in points were used for calculation of integral vectors of groundwater contamination.

\section{RESULTS AND DISCUSSION}

As a result of field studies, we found that the concentration of the compounds in the soil and crops during the vegetation season was gradually decreasing and was not found at harvest. Based on the evidence on the dynamics of residual amounts of these substances in soil, the $\mathrm{DT}_{50}$ values were calculated. According to obtained data and to "Hygienic classification of pesticides and agrochemicals" State Standards 8.8.1.002-98 [16] herbicides isoxaflutole and mesotrione pertain to hazard class 4 (unstable); fungicides topramezone, fluxapyroxad, cyflufenamid, famoxadone, oxathiapiprolin and herbicide metribuzin - to class 3 (moderately stable); herbicide flufenacet and insecticides thiamethoxam, imidacloprid - to class 2 (stable) Other studied compounds - class 1 (stable).

We have calculated the ecotox values of studied substances in the agro-climatic conditions of Ukraine (table. 1). Their values range between $1,20 \times 10^{-6}$ and $2,75 \times 10^{-1}$ for herbicides; between $1,18 \times 10^{-5}$ and $2,40 \times 10^{-3}$ for fungicides and between $2,79 \times 10^{-3}$ and $1,26 \times 10^{-2}$ for insecticides. Thus, ecotoxicological hazard of studied herbicides by (1-6) orders of magnitude, fungicides - by (3-5) orders, insecticides by (2-3) orders lower than DDT.
It can also be concluded that the least ecotoxic are herbicides of the last generations, then - fungicides, and the most ecotoxic are insecticides and herbicides of the old first generations (table 1).

Evaluation of hazard to the environment of test substances except for ecotoxicological hazard prediction, involves determining the potential risk of groundwater contamination in rural areas, which are widely used as a source of decentralized drinking water supply.

The integrated vectors were calculated for the prediction of groundwater pollution with test groups of pesticides. Initial data and results of GUS and Z biol.ef. calculations are shown in table 2 .

The values of the indicators were expressed in points, and then integral vectors of hazard of groundwater contamination were calculated and evaluated according to a scale provided in [6]. The results are shown in table 3.

The data in table 3 indicate a high danger of groundwater contamination in the soil and climatic conditions of Ukraine with studied herbicides, insecticides and fungicides. except for mesotrione, the application of which is of danger for secondary contamination of groundwater. There is a moderate hazard of groundwater contamination with mesotrione, which is an exception among all studied pesticides.

The high danger of groundwater contamination with topramezone, isoxaflutole, famoxadone is determined mainly by their toxicity and cumulativeness in warm-blooded animals. Fluxapyroxad, oxathiapiprolin, imidacloprid, flufenacet, diquat have high hydrolytic stability, cyflufenamide, difenoconazole - have both characteristics.

At the same time, all of these substances, except for metribuzin, thiamethoxam, paclobutrazole, have average or low ability to migrate from the soil into groundwater. In terms of observance of hygienic standards in the soil, this allows to avoid them from getting into the soil flow.

In soil and climatic conditions of Ukraine according to GUS indeces hazard of the test substances migration from the soil into groundwater is: for metribuzin, thiamethoxam, paclobutrazole high, topramezone and mesotrione - moderate, for the rest of substances - low. The above mentioned suggests necessity of considering migration process of metribuzin, thiamethoxam, paclobutrazole in the "soil-groundwater" system in justifying their hygiene standards in soil using calculation method. 
Table 1

Comparative assessment of ecotoxicological hazard of different groups, classes and generations of pesticides

\begin{tabular}{|c|c|c|c|c|}
\hline Mode of action class & Chemical class & Substance & Ecotox & Reference \\
\hline \multicolumn{5}{|c|}{ Herbicides } \\
\hline \multirow[t]{6}{*}{ Photosynthesis inhibitors } & triazines & simazine & $7,45 \times 10^{-2}$ & [12] \\
\hline & & atrazine & $3,09 \times 10^{-2}$ & \\
\hline & & propazine & $1,17 \times 10^{-2}$ & \\
\hline & benzothiadiazinone & bentazone & $1,02 \times 10^{-2}$ & \\
\hline & triazinones & metribuzin & $3,00 \times 10^{-3}$ & \\
\hline & & & & $\mathbf{A} \mathbf{R}^{2}$ \\
\hline \multirow{9}{*}{$\begin{array}{l}\text { ALS }^{1} \\
\text { inhibitors }\end{array}$} & imidazolinones & imazethapyr & $2,07 \times 10^{-4}$ & [5] \\
\hline & & imazapyr & $3,00 \times 10^{-5}$ & \\
\hline & & imazamox & $1,60 \times 10^{-5}$ & \\
\hline & sulfonylureas & prosulfuron & $3,04 \times 10^{-5}$ & [7] \\
\hline & & foramsulfuron & $1,90 \times 10^{-5}$ & \\
\hline & & tritosulfuron & $1,60 \times 10^{-5}$ & \\
\hline & & tribenuron-methyl & $3,76 \times 10^{-6}$ & \\
\hline & & triasulfuron & $1,24 \times 10^{-6}$ & [1] \\
\hline & & $\begin{array}{l}\text { iodosulfuron } \\
\text {-methyl-sodium }\end{array}$ & $1,20 \times 10^{-6}$ & \\
\hline Inhibition of cell division & oxyacetamide & flufenacet & $3,89 \times 10^{-2}$ & [2] \\
\hline PS-I-electron diversion & bipyridylium & diquat & $2,75 \times 10^{-1}$ & \\
\hline \multirow{3}{*}{$\begin{array}{l}\text { Inhibition of pigment } \\
\text { synthesis }\end{array}$} & benzoylpyrazoles & topramezone & $8,25 \times 10^{-5}$ & \\
\hline & triketone & mesotrione & $3,90 \times 10^{-5}$ & \\
\hline & oxazole & isoxaflutole & $2,48 \times 10^{-5}$ & \\
\hline \multicolumn{5}{|c|}{ Insecticides } \\
\hline \multirow{2}{*}{$\begin{array}{l}\text { Nicotinic acetylcholine } \\
\text { receptor agonists }\end{array}$} & \multirow[t]{2}{*}{ neonicotinoid } & thiamethoxam & $1,20 \times 10^{-6}$ & $\overline{\mathbf{A R}}$ \\
\hline & & imidacloprid & $1,20 \times 10^{-6}$ & \\
\hline \multicolumn{5}{|c|}{ Fungicides } \\
\hline \multirow[t]{3}{*}{ SDHI $^{3}$ inhibitors } & pyrazole -4- carboxamides & fluxapyroxad & $1,39 \times 10^{-4}$ & $\overline{A R}$ \\
\hline & amide & cyflufenamide & $4,18 \times 10^{-5}$ & \\
\hline & pyridine carboxamides & boscalid & $2,7 \times 10^{-4}$ & [3] \\
\hline \multirow{6}{*}{$\begin{array}{l}\text { Inhibitors of complex III } \\
\text { cytochrome bc1 (ubiquinol } \\
\text { oxidase) at Qo site }\end{array}$} & oximino- & kresoxim-methyl & $1,60 \times 10^{-4}$ & [9] \\
\hline & & trifloxystrobin & $1,20 \times 10^{-4}$ & \\
\hline & & & $0,6 \pm 0,1 \times 10^{-4}$ & [3] \\
\hline & $\begin{array}{l}\text { methoxy- } \\
\text { carbamates }\end{array}$ & pyraclostrobin & $0,7 \pm 0,2 \times 10^{-4}$ & \\
\hline & $\begin{array}{l}\text { methoxy- } \\
\text { acrylates }\end{array}$ & azoxystrobin & $1,7 \times 10^{-4}$ & \\
\hline & $\begin{array}{l}\text { oxazolidine- } \\
\text { diones }\end{array}$ & famoxadone & $2,2 \times 10^{-3}$ & $\mathbf{A R}$ \\
\hline \multirow{5}{*}{$\begin{array}{l}\text { Inhibitors C14-demethylase } \\
\text { in sterol biosynthesis }\end{array}$} & triazoles & tebuconazole & $2,4 \pm 1,2 \times 10^{-4}$ & [3] \\
\hline & & penconazole & $2,2 \pm 1,0 \times 10^{-4}$ & \\
\hline & & difenoconazole & $7,0 \pm 1,8 \times 10^{-4}$ & \\
\hline & & & $1,9 \times 10^{-3}$ & $\mathbf{A R}$ \\
\hline & & paclobutrazole & $2,4 \times 10^{-3}$ & \\
\hline \multirow{2}{*}{$\begin{array}{l}\text { Oxidation enzymes } \\
\text { inhibitors }\end{array}$} & dithiocarbamates & metiram & $9,5 \times 10^{-4}$ & [4] \\
\hline & & mancozeb & $7,00 \times 10^{-4}$ & [4] \\
\hline \multirow[t]{2}{*}{ Osmotic signal transductor } & cyanopyrrole & fludioxonil & $2,0 \times 10^{-4}$ & [3] \\
\hline & piperidinyl thiazole isoxazoline & oxathiapiprolin & $2,2 \times 10^{-4}$ & $\mathbf{A R}$ \\
\hline
\end{tabular}


Table 2

Migration, stability and toxicity parameters of studied pesticides

\begin{tabular}{|c|c|c|c|c|c|c|c|}
\hline Substance & $\begin{array}{l}\mathrm{DT}_{50}{ }^{1} \text { in soil, } \\
\text { day }\end{array}$ & $\begin{array}{c}\mathrm{K}_{\mathrm{oc}}^{2}, \mathrm{ml} / \mathrm{g} \\
{[8]}\end{array}$ & GUS $^{3}$ & $\begin{array}{c}\mathrm{DT}_{50}{ }^{1} \text { in water, } \\
\text { day }[8]\end{array}$ & $\begin{array}{c}\mathrm{LD}_{50}{ }^{4}, \mathrm{mg} / \mathrm{kg} \\
{[8]}\end{array}$ & $\underset{[8]}{\operatorname{Lim}_{\mathrm{ch}}{ }^{5}}$ & $Z$ biol.ef. ${ }^{6}$ \\
\hline \multicolumn{8}{|c|}{ Herbicides } \\
\hline Metribuzin & 22,8 & 37.92 & 3.2 & 34 & 322 & 1,3 & 247,7 \\
\hline Flufenacet & 38,8 & 401 & 2.1 & stable & 598 & 1,14 & 524,6 \\
\hline Diquat & 98,1 & 2185000 & -4.2 & stable & 214 & 0,5 & 428,0 \\
\hline Topramezone & 15,7 & 93 & 2,40 & 30 & 2000 & 0,4 & 5000,0 \\
\hline Isoxaflutole & 7,9 & 112 & 1,80 & 11 & 5000 & 2,0 & 2500,0 \\
\hline Mesotrione & 8,8 & 80 & 1,97 & $>\mathbf{3 0}$ & 5000 & 154,0 & 32,5 \\
\hline
\end{tabular}

Insecticides

\begin{tabular}{|c|c|c|c|c|c|c|c|}
\hline Thiamethoxam & 48,6 & 56.2 & 3.78 & 11,5 & $>1563$ & 2,6 & 601,2 \\
\hline Imidacloprid & 47,1 & 225 & 2.6 & 1 рік & 131 & 6,0 & 21,8 \\
\hline
\end{tabular}

Fungicides

\begin{tabular}{lccccccc}
\hline Fluxapyroxad & 30,8 & 728 & 1,70 & $>100$ & 2000 & 2,1 & 952,4 \\
Cyflufenamide & 19,6 & 1595 & 1,04 & 642 & 5000 & 1,04 & 4807,5 \\
Famoxadone & 16,9 & 3847 & 0.48 & 2 & $>5000$ & 1,2 & 4166,7 \\
Difenoconazole & 70,9 & $400-7730$ & 1.96 & стаб. & 1453 & 1,0 & 1453 \\
Paclobutrazole & 155,9 & 400 & 3.49 & 30 & 1336 & 2,2 & 607,3 \\
Oxathiapiprolin & 18,7 & 9673.8 & 0.01 & cтаб. & $>5000$ & 104 & 48,1 \\
\hline
\end{tabular}

N o t a s : $1 . \mathrm{DT}_{50}$ - half-life period; $2 . \mathrm{K}_{\mathrm{oc}}$ - organic carbon sorption constant; 3 . GUS - groundwater ubiquity score; 4 . LD ${ }_{50}-$ per oral half lethal concentration; 5 . Lim $_{\mathrm{ch}}-$ limit of chronic effect; 6 . $\mathrm{Z}$ biol.ef. - zone of biological effect. 
Integral assessment of groundwater contamination hazard with studied pesticides

\begin{tabular}{|c|c|c|c|c|c|}
\hline \multirow{2}{*}{ Substance } & \multicolumn{4}{|c|}{ Indices values, score } & \multirow{2}{*}{ Level of hazard } \\
\hline & GUS & Water hydrolysis & $\mathrm{Z}$ biol.ef. & Integral hazard vector $(\mathbf{R})$ & \\
\hline \multicolumn{6}{|c|}{ Herbicides } \\
\hline Metribuzin & 80 & 50 & 50 & 106,8 & high \\
\hline Flufenacet & 50 & 100 & 50 & 122,5 & high \\
\hline Diquat & 30 & 100 & 50 & 115,8 & high \\
\hline Topramezone & 50 & 50 & 80 & 106,8 & high \\
\hline Isoxaflutole & 50 & 30 & 80 & $\mathbf{9 8 , 9}$ & high \\
\hline Mesotrione & 50 & 50 & 30 & 76,8 & moderate \\
\hline
\end{tabular}

Insecticides

\begin{tabular}{|c|c|c|c|c|c|}
\hline Thiamethoxam & 80 & 30 & 50 & 98,9 & high \\
\hline Imidacloprid & 50 & 100 & 30 & 115,8 & high \\
\hline
\end{tabular}

Fungicides

\begin{tabular}{|c|c|c|c|c|c|}
\hline Fluxapyroxad & 30 & 80 & 50 & 99,0 & high \\
\hline Cyflufenamide & 30 & 80 & 80 & 117,0 & high \\
\hline Famoxadone & 30 & 30 & 80 & 90,6 & high \\
\hline Difenoconazole & 50 & 100 & 80 & 137,5 & high \\
\hline Paclobutrazole & 80 & 30 & 50 & 98,9 & high \\
\hline Oxathiapiprolin & 30 & 100 & 30 & 108,6 & high \\
\hline
\end{tabular}

\section{CONCLUSIONS}

1. It was established that in soil and climatic conditions of Ukraine ecotoxicological hazard of studied herbicides by (1-6) orders, fungicides - by (3-5) orders, insecticides - by (2-3) orders of magni- tude lower than DDT. The least ecotoxic are herbicides of the last generations, then - fungicides, and the most ecotoxic are insecticides and herbicides of old first generations. 
2. It was proved a high danger of groundwater contamination with studied herbicides, insecticides and fungicides, except for mesotrione, the application of which has moderate danger in the soil and climatic conditions of Ukraine.

3. It was shown that in soil and climatic conditions of Ukraine ability of migration of metribuzin, thiamethoxam, paclobutrazole from the soil into groundwater is high, topramezone and mesotrione moderate, of other substances - low, in terms of following of hygienic standards in the ground this allows to avoid them from getting into the soil and to minimize the danger to public health of groundwater contamination.

\section{REFERENCES}

1. Antonenko AM. [Hygienic safety regulations justify the use of modern herbicides in corn chemical protection systems]. [dissertation]. Kyiv, 2012;24. Ukrainian.

2. Antonenko AM. [Ecotoxicological hazard assessment and risk of groundwater contamination by new pesticides 4-hydroxyphenylpyruvat dioxygenase inhibitors and inhibitors of microsomal enzymes]. Aktual'ni problemy suchasnoyi medytsyny. 2014;14(3):43-47. Ukrainian.

3. Vavrinevich YeP, Bardov VG, Omelchuk ST. [Comparative ecological and hygienic assessment of the behavior and persistence of fungicides of different classes in soil]. Zdorove i okruzhayushchaya sreda, Minsk. RNMB, 2014;1(24):138-43. Russian.

4. Vavrinevych OP, Omel'chuk ST, Bardov VH. [Toxicological and hygienic evaluation of the use of fungicides class ethylene-bis-dithiocarbamates modern technologies of chemical crop protection]. Visnyk VDNZU «Ukrayins'ka medychna stomatolohichna akademiya». 2014;14(1):43-48. Ukrainian.

5. Dema OV. [Hygienic regulations justify the use of herbicides in agriculture based imazetherapy]. [dissertation]. Kyiv, 2007;21. Ukrainian.

6. Sergeev SG, et al. [Indicative criteria and forecast of the danger of groundwater contamination with herbicides on the basis of acid esters]. Sovremennye problemy toksikologii. 2010;2(3):76-79. Russian.

7. Karpenko VV. [Hygienic evaluation of herbicides - sulfonylurea and scientific substantiation of safety regulations of applying to cereals]. [dissertation], Natsional'nyy medychnyy universytet imeni O.O. Bohomol'tsya. Kyyiv, 2009;23. Ukrainian.

8. Pesticides property database, PPDB: [Electronic source]. Available from: http://www.rupest.ru/ppdb. Russian.
9. Korshun OM. [Environmental and safety regulations justification of safe use of modern chemical protection of apple orchards]. [dissertation]. Kyiv, 2008;20. Ukrainian.

10. Larina GYe. [Methodology of ecological and toxicological monitoring of herbicides in the agroecosystem (on the example of sulfonylurea and imidazolinone): the author's abstract]. [dissertation]. Moskva, 2006;39. Russian.

11. Melnikov NN. [On the issue of soil contamination with organochlorine compounds]. Agrokhimiya. 1996;10:72-74. Russian.

12. Melnikov NN, Belan SR. [Comparative danger of soil contamination with herbicides - derivatives of simtriazines and some other six-membered heterocyclic compounds]. Agrokhimiya. 1997;2:66-67. Russian.

13. [Methodological instructions for controlling levels and studying the dynamics of pesticide content in soil and plants]. Moskva, Agropromizdat, 1985;58. Russian.

14. [Methodological instructions for processing the results of studying the dynamics of pesticides in soil and plants]. Moskva, Gos. Agropromyshlennyy komitet SSSR, 1985;40. Russian.

15. Onishchenko GG. [Hygienic aspects of ensuring environmental safety in handling pesticides and agrochemicals]. Gigiena i sanitariya. 2003;3:3-5. Russian.

16. [SSanRN 8.8.1.002-98. Hygienic classification of pesticides by hazard]. Approv. By Ministry of Health of Ukraine; 1998. Ukrainian.

17. Serdyuk AM, Korzun VN, Kalinkin MN, et al. [Strengthening and preservation of human health - a common cause for students of different countries]. Dovkillya ta zdorov'ya. 2010;1(52):3-8. Russian.

\section{СПИСОК ЛІТЕРАТУРИ}

1. Антоненко А.М. Гігієнічне обгрунтування регламентів безпечного застосування сучасних гербіцидів в системах хімічного захисту кукурудзи: автореф. дис. на здобуття наук. ступеня канд. мед. наук: спец. 14.02.01 «Гігієна та професійна патологія»/ А.М. Антоненко. - Київ, 2012. - 24 с.

2. Антоненко А.М. Оцінка екотоксикологічної небезпечності та ризику забруднення підземних вод новими пестицидами інгібіторами 4-гідроксифенілпіруватіоксигенази та інгібіторами мікросомальних ферментів / А.М. Антоненко // Актуальні проблеми сучасної медицини: Вісник Української медичної стоматологічної академії. - 2014. - Т. 14, Вип. 3 (47). - С. 43-47.

3. Вавриневич Е.П. Сравнительная эколого-гигиеническая оценка поведения и персистентности фунгицидов разных классов в почве / Е.П. Вавриневич, В.Г. Бардов, С.Т. Омельчук // Здоровье и окружающая среда: сб. науч.тр. - Минск: РНМБ, 2014. Т.1, Вып. 24. - С. 138-143.

4. Вавріневич О.П. Токсиколого-гігієнічна оцінка застосування фунгіцидів класу етилен-біс-дитіокарбаматів в сучасних технологіях хімічного захисту сільськогосподарських культур / О.П. Вавріневич, 
С.Т. Омельчук, В.Г. Бардов // Вісник ВДНЗУ «Українська медична стоматологічна академія». - 2014 Т. 14, Вип. 1 (45). - С. 43-48.

5. Дема О.В. Гігієнічне обгрунтування регламентів використання в сільському господарстві гербіцидів на основі імазетапіру: автореф. дис. на здобуття наук. ступеня. канд. мед. наук: спец. 14.02.01 «Гігієна» / О.В. Дема. - Киев, 2007. - 21 с.

6. Индикаторные критерии и прогноз опасности загрязнения подземных вод гербицидами на основе эфиров кислот / С.Г. Сергеев [и др.] // Соврем. проблемы токсикологии. - 2010. - № 2-3. - С. 76-79.

7. Карпенко В.В. Гігієнічна оцінка гербіцидів похідних сульфонілсечовини та наукове обгрунтування регламентів їх безпечного застосування на зернових культурах: автореф. дис. на здобуття наук. ступеня канд. мед. наук: спец. 14.02.01 «Гігієна та професійна патологія» / В.В. Карпенко. - Київ, 2009. $-23 \mathrm{c}$.

8. Каталог пестицидов // PPDB: [Електронний pecypc. — Режим доступу: http://www.rupest.ru/ppdb.

9. Коршун О.М. Еколого-гігієнічне обгрунтування регламентів безпечного застосування сучасних хімічних засобів захисту яблуневих садів: автореф. дис. на здобуття наук. ступеня. канд. біол. наук: спец. 14.02 .01 «Гігієна та професійна патологія» / О.М. Коршун. - Киев, 2008. - 20 с.

10. Ларина Г.Е. Методология эколого-токсикологического мониторинга гербицидов в агроэкосистеме (на примере сульфонилмочевины и имидазолинона): автореф. дис. на соискание учен. степени канд. с.-х. наук: спец. 03.00.16 «Экология» / Г.И. Ларина. Москва, 2006. - 39 с.

11. Мельников Н.Н. К вопросу о загрязнении почвы хлорорганическими соединениями / Н.Н. Мельников. - Агрохимия. - 1996. - № 10. — С. 72-74.

12. Мельников Н.Н. Сравнительная опасность загрязнения почвы гербицидами - производными симм-триазинов и некоторых других шестичленных гетероциклических соединений / Н.Н. Мельников, С.Р. Белан // Агрохимия. — 1997. — № 2. - С. 66-67.

13. Методические указания по контролю уровней и изучению динамики содержания пестицидов в почве и растениях / М-во сельского хозяйства СССР. Москва: Агропромиздат, 1985. - 58 с.

14. Методические указания по обработке результатов изучения динамики пестицидов в почве и растениях. - [Утв. 05.11.85]. - Москва: Гос. Агропромышленный комитет СССР, 1985. - 40 с.

15. Онищенко Г.Г. Гигиенические аспекты обеспечения экологической безопасности при обращении с пестицидами и агрохимикатами / Г.Г. Онищенко // Гигиена и санитария. - 2003. - № 3. - С. 3-5.

16. Пестициди. Класифікація за ступенем небезпечності: ДСанПіН 8.8.1.002-98 - [Затв. 28.08.98] // 3б. важливих офіційних матеріалів з санітарних і протиепідемічних питань. - Київ, 2000. - Т. 9. - Ч. 1. - С. 249-266.

17. Укрепление и сохранение здоровья человека - общее дело учених разных стран / А.М. Сердюк, В.Н. Корзун, М.Н. Калинкин [и др.] // Довкілля та здоров'я. — 2010. — № 1 (52). — С. 3-8.

Стаття надійшла до редакції 05.04 .2017 